\title{
Öğrencilerin Okul Olgunluklarının Okuma Yazma Sürecine Etkisi
}

DOI: 10.26466/opus.913538

\author{
* \\ Muhittin Sağırlı* - Leyla Coşkun ** \\ * Dr. Öğr. Üyesi, İstanbul Üni. - Cerrahpaşa / Hasan Âli Yücel Eğitim Fak., İstanbul / Türkiye \\ E-Posta: muhittinsagirli@istanbul.edu.tr ORCID: 0000-0001-9558-3891 \\ ** Sınıf Öğr. ve Marmara Üniv.Eğtim Bilimleri Enstitüsü Temel Eğitim Sınıf Öğretmenliği Doktora \\ Programı Öğrencisi / İstanbul / Türkiye \\ E-Posta: lleylacoskun@gmail.com \\ ORCID: $\underline{0000-0003-4932-2927}$
}

\section{Öz}

Birinci sınıfa başlayan öğrenciler, yalnızca takvim yaşları dikkate alınarak okula başlatılmaktadır. Bu durum öğrencilerin okul olgunlukları düzeylerinin göz ardı edilmesine sebep olmaktadır. Okul olgunluk düzeyleri dikkate alınmadan okula başlayan çocuklar, okulla birlikte çoğu ilk kez olmak üzere ciddi süreçler ile karşı karşıya gelmektedir. Bu süreçlerden biri de öğrencilerin, ilkokul 1. sınıfta ilk olarak karşılaştıkları okuma yazma sürecidir. Bu araştırmanın amacı, ilkokul 1. sınıfa başlayan öğrencilerin, okul olgunluklarının okuma yazma sürecine etkisi ile ilgili öğretmen görüşlerinin incelenmesidir. Araştırmada, öğrencilerin okul olgunluklarının okula uyum, motor beceri, sosyal beceriler, kurallara uyma ve öz bakım becerisi bakımından okuma yazma sürecine olan etkisi öğretmen görüşleri ile incelenmiştir. Bu araştırmada nitel araştırma desenlerinden durum çalışması kullanılmıştır. Araştırmanın çalışma grubunu, 2020-2021 eğitim - öğretim döneminde İstanbul iline bağgl farkl devlet okullarında görev yapmakta olan, en az iki kez birinci sınıfta eğitim-öğretimi yürütmüş 15 sinıf öğretmeni oluşturmaktadır. Araştırmada veri toplama aracı olarak araştırmacilar tarafindan oluşturulan yarı yapılandırılmış görüşme formu kullanılmışıır. Verilerin analizinde, nitel veri analizi tekniklerinden betimsel analiz kullanılmıştır. Araştırmada elde edilen bulgulardan hareketle ilkokul 1.sını öğrencilerinin okul olgunluklarmin okula uyum, sosyal beceriler, kurallara uyma ve öz bakım becerisi bakımından okuma yazma sürecini etkilediği sonucuna ulaşılmıştır.

Anahtar Kelimeler: Okul Olgunluğu, İlk okuma yazma Süreci, İlkokul Birinci Sını,, Birinci Sinıf Öğretmeni. 
ISSN: 2528-9527

E-ISSN : 2528-9535

Yıl Year: 11

Cilt Volume: 17

Sayı Issue:37

Mayıs May 2021

Makalenin Geliș Tarihi Received Date. 12/03/2021

Makalenin Kabul Tarihi Accepted Date. 25/05/2021

\title{
The Effect of Student' School Maturity on the Literacy Process
}

\begin{abstract}
Students start the first year of school only based on their age which means ignoring their school maturity levels. Children who start school regardless of their school maturity level are faced with the processes brought about by the school. One of these processes is the literacy process that students first encounter when they start primary school. The aim of this study is to examine teachers' opinions about the effect of school maturity of students starting the first grade of primary school on the literacy process. In the study, the effect of students 'school readiness on the literacy process in terms of school adjustment, motor skills, social skills, obedience to rules and self-care skills was examined with the teachers' opinions. In this study, one of the qualitative research designs, case study was used. The sample of the research consists of 15 easily accessible classroom teachers who work in different public schools in Istanbul during the 2020-2021 academic year and have taught first grades for at least two times. In the research, a semistructured interview form created by the researchers was used as the data collection tool. Descriptive analysis, one of the qualitative data analysis techniques, was used in the analysis of the data. Based on the findings of the study, it was concluded that the school maturity of primary school first grade students affected the literacy process in terms of school adaptation, social skills, obedience to rules and self-care skills.
\end{abstract}

Keywords: School Maturity, First Literacy Teaching Process, First Grade, First Grade Teacher 


\section{Giriş}

Bireylerin ilkokul yaşamları, ilk okuma yazma süreciyle başlamaktadır. Okullarımızda, ilk okuma yazma öğretimi, birinci sınıfa başlayan her öğrenciye Türkçe dersi kapsamında verilmektedir. Öğrencinin birinci sınıfa başlaması için temel alınan kıstas ise bireyin takvim yaşıdır. Ülkemizde ilkokul birinci sınıfa başlayacak çocuklar, aşağıdaki maddeler doğrultusunda okula başlatılmaktadır (Resmi Gazete, 2019).

a) "İlkokulların birinci sınıfına, kayıtların yapıldığı yılın eylül ayı sonu itibarıyla 69 ayını dolduran çocukların kaydı yapılır. Ayrıca 66, 67 ve 68 aylık çocuklardan velisinin yazılı isteği bulunanlar da ilkokul birinci sinufa kaydedilir.

b) Okul müdürlükleri, yaşça kayıt hakkını elde eden çocuklardan 69, 70 ve 71 aylık olanları velisinin yazılı talebi bulunması halinde okul öncesi eğitime yönlendirir veya kayıtlarını bir yıl erteler."

Bu maddelerde belirtilen yaş aralıkları, çocuğun okula başlamasıyla ilgili genel bir bilgi vermektedir. Bu genel bilgi göz önüne alınarak okula başlayan öğrencinin okuma yazma sürecine hazır olduğu kabul edilmektedir. Böylece öğrencilerin, yalnızca bulundukları yaş aralıklarının dikkate alınmasıyla, okulda geçirecekleri süreçlerde başarılı olmaları için gerekli olgunluk seviyelerine ulaşmış oldukları varsayılmaktadır. Ancak burada, öğrencilerin okul yaşantılarına dolayısıyla bu yaşantının önemli bir basamağı olan okuma yazma öğretim sürecine etki etmekte olan okul olgunluğu kavramı ve öğrencilerin okul olgunluk düzeyleri karşımıza çıkmaktadır. İlgili literatüre bakıldığında okul olgunluğu ile ilgili değişik tanımlar yapıldığı görülmektedir. Okul olgunluğu, öğrenmeye hazır olma ve sınıf içinde uygun davranışlar göstermeye hazır olma durumlarını içeren bir kavramdır (Carlton ve Winsler, 1999). Yavuzer'e (2002) göre okul olgunluğu; çocuğun kazanması beklenilen becerilere ve okula bedensel, zihinsel ve sosyal açıdan hazır olmasıdır. Oktay'a (1983) (Akt. Cinkılıç, 2009) göre ise okul olgunluğu; öğrencinin okuma yazma öğrenmesi için gerekli olgunlukta olmasına ilaveten bu süreç için gereken bilgi, beceri ve tutuma da sahip olmasıdır. Okul olgunluğu, çocuğun okul içinde bir birey olarak genel başarı gösterme durumudur.

Okul olgunluğu; çocuğun sağlıklı ve düzenli bir aile ortamında bedensel, zihinsel ve duygusal yönden belirli düzeyde gelişimini sağlayıp ruhsal ve toplumsal yönden evinden, yakın çevresinden süreli ayrılabilecek olgunluğa 
gelmiş olmasıdır. Bu açıdan düşünüldüğünde okul olgunluğu 1. sınıfa başlayacak olan çocuğun anneden ayrılma, okuldaki çevresiyle iletişime geçme, yeni arkadaşlıklar edinme, okul kurallarına uyma, okul içinde sınıfını ve öğretmenini kabullenme, okulda bulunduğu sürede tuvalet ihtiyacını ve beslenme ihtiyacını karşılayabilme, derslerde başarılı olabileceğine inanma, özgüvene sahip olma gibi birçok açıdan belirli düzeyde gelişmiş olmasını ifade etmektedir (Sağırlı, 2019).

Birinci sınıfa başlamadan önce çocukların okul olgunlukları ile ilgili herhangi bir kıstas üzerinden değerlendirme yapılmamaktadır. Bu da 1.sınıfa başlayan çocukta yukarıda bahsettiğimiz gibi okula bedensel, zihinsel ve sosyal açıdan hazır olma durumlarının göz ardı edilmesine sebep olmaktadır. Oysa okuma yazma sürecinde edinilen beceriler ve bu süreçteki deneyimler çocuğun ileride yaşayacağı deneyim ve becerilerin temelini oluşturmaktadır (Babayiğit ve Erkuş, 2016).

Farklı alanlardaki beceriler bakımından gelişmiş seviyeye ulaşabilen çocukların okul hayatlarında daha mutlu, uyumlu ve başarılı olma ihtimalleri diğer çocuklara göre daha yüksektir (Tuğrul 2003; akt: Erkan, 2011). Çocuğun okuma yazma sürecine hazır olmadığı bir ortama sokulması okula ve okulla birlikte edineceği yaşantılara karşı olumsuz bir tutum edinmesine sebep olmaktadır (Arı ve Özcan, 2014).

Bütün bunlar göz önünde bulundurulduğunda, çocukların okul olgunluğuna erişip erişemediklerine bakılmaksızın birinci sınıfa başlatılmalarının okuma yazma sürecine etki ettiği görülmektedir. Bu durum araştırmanın çıkış noktası olmuştur.

$\mathrm{Bu}$ araştırmanın amacı, 1.sınıfa başlayan öğrencilerin okul olgunluklarının okuma yazma sürecine etkisi ile ilgili öğretmen görüşlerinin incelenmesidir. Araştırmada, öğrencilerin okul olgunluklarının okula uyum, motor beceri, sosyal beceriler, kurallara uyma ve öz bakım becerisi bakımından okuma yazma sürecine olan etkisi öğretmen görüşleri ile incelenmiştir. Bu doğrultuda aşağıdaki sorulara cevap aranmıştır:

1. Öğrencilerin okul olgunluklarının okula uyum bakımından okuma yazma sürecine etkisi nasıldır?

2. Öğrencilerin okul olgunluklarının motor gelişim bakımından okuma yazma sürecine etkisi nasıldır?

3. Öğrencilerin okul olgunluklarının sosyal beceriler bakımından okuma yazma sürecine etkisi nasıldır? 
4. Öğrencilerin okul olgunluklarının öz bakım becerileri bakımından okuma yazma sürecine etkisi nasıldır?

5. Öğrencilerin okul olgunluklarının kurallara uyma bakımından okuma yazma sürecine etkisi nasıldır?

Ülkemizde ilkokula başlama çağına gelen çocukların, okula kayıt sırasında yalnızca yaş aralığına bakılarak kaydedilmeleri farklı okul olgunluklarına sahip çocukların aynı sınıflarda eğitim öğretime başlamalarına sebep olmaktadır. Bu nedenle, aynı yaş aralığında olmalarına rağmen farklı okul olgunluğuna sahip olmaları öğrencilerin okuma yazma sürecine etki etmektedir.

$\mathrm{Bu}$ araştırma, ilkokul 1. sınıf öğrencilerinin okul olgunluklarının okuma yazma sürecine etkisinin okula uyum, sosyal beceriler, kurallara uyma, öz bakım becerisi bakımından incelenmesi açısından ve alan yazında okul olgunluğu kavramının okuma yazmaya etkisini bu bakımlardan inceleyen çok sayıda çalışmaya rastlanmaması nedeniyle alan yazına farklı bir katkı sağlaması açısından önemlidir.

\section{Yöntem}

\section{Araştırmanın Modeli}

Araştırmada ilkokul 1.sınıf öğrencilerinin okul olgunluklarının okuma yazma sürecine etkisi ile ilgili öğretmen görüşleri incelenmiştir. Bu araştırmada nitel araştırma desenlerinden durum çalışması kullanılmıştır. "Durum çalışmalarında, bir birey, bir kurum, bir grup, bir ortam çalış1lacak durumlara örnek oluşturabilir. Amaç belli bir duruma ilişkin sonuçları ortaya koymaktır. Nitel durum çalışmasının en temel özelliği bir ya da birkaç durumun derinliğine araştırılmasıdır. Yani bir duruma ilişkin etkenler (ortam, bireyler, olaylar, süreçler, vb.) bütüncül bir yaklaşımla araştırılır ve ilgili durumu nasıl etkiledikleri ve ilgili durumdan nasıl etkilendikleri üzerine odaklanılır" (Yıldırım ve Şimşek, 2018).

\section{Örneklem}

Araştırmanın çalışma grubunu, 2020-2021 eğitim- öğretim döneminde İstanbul iline bağlı farklı devlet okullarında görev yapmakta ve en az iki defa birinci sınıfta eğitim-öğretim faaliyetlerini yürütmüş 15 sınıf öğretmeni 
oluşturmaktadır. Çalışma grubunu belirlerken yöntem olarak amaçlı örnekleme yöntemlerinden kolay ulaşlabilir durum örneklemesi kullanılmıştır. "Kolay ulaşılabilir durum örneklemesi, araştırmaya hız ve pratiklik kazandırır. Bu yöntemde araştırmacı yakın olan ve erişilmesi kolay bir durumu seçer"' (Yıldırım ve Şimşek, 2018). Aşağıda araştırmaya katılan öğretmenlerinin demografik özellikleri Tablo 1'de görülmektedir.

Tablo 1. Katılımcılarn demografik özellikleri

\begin{tabular}{lll}
\hline Değişken & Grup & f \\
\hline Cinsiyet & Kadın & 9 \\
& Erkek & 6 \\
\hline Yaş & $25-30$ & 2 \\
& $31-35$ & 7 \\
& $36-40$ & 3 \\
& $41-45$ & 2 \\
\hline Mesleki Kıdem & $50-55$ & 1 \\
& $2-5$ & 3 \\
& $6-10$ & 7 \\
\hline 1. Sınıflarda Eğitim Öğretim Yürü̈tme Sayısı & $10-15$ & 4 \\
& 30 ve Üstü & 1 \\
\hline Toplam & 2 & 4 \\
& 3 & 6 \\
\hline
\end{tabular}

Tablo 1'e göre; araştırmaya katılan 15 sınıf öğretmenin, 9 tanesi kadın ve 6 tanesi erkek öğretmenlerden oluşmaktadır. Çalışmaya katılan öğretmenlerin en az 2 kez, en çok 12 kez birinci sınıflarda eğitim- öğretim yürüttükleri görülmektedir.

\section{Veri Toplama Araçları}

Araştırma, gerekli Etik Kurul izni alınarak yapılmıştır (2021/55 Sayılı E. K. Onayı Sayı: E-74555795-050.01.04-54302). Nitel araştırma yöntemlerinden durum çalışmasının kullanıldığı araştırmada veri toplamak amacıyla katılımc1lara, araştırmacılar tarafından oluşturulmuş açık uçlu sorulardan oluşan yarı yapılandırılmış görüşme formu gönderilmiştir. Araştırma, 2020-2021 eğitim- 
öğretim yılında yürütülmüştür. Bu nedenle Covıd19 salgını döneminde uygulanan anketler katılımclara Google Form olarak iletilmiştir. Katılımcıların anketlere vermiş oldukları cevaplar Google form üzerinde alınmış ve kaydedilmiştir.

\section{Verilerin Analizi}

$\mathrm{Bu}$ çalışmada veri analizinde nitel veri analiz yöntemlerinden içerik analizi yapılmıştır. İçerik analizinde, benzer veriler belli kavramlar ve temalar çerçevesinde toplanarak, düzenlenerek yorumlanır (Yıldırım ve Şimşek, 2018).

Bu doğrultuda toplanan veriler; öğretmen 1 (Ö1), öğretmen 2 (Ö2), ... şeklinde kodlanarak tek tek okunmuştur. Elde edilen verilerden benzer kodlar oluşturulmuş, oluşan kodlar temalar altında toplanarak incelenmiştir. Cevaplar sayısallaştırılmış ve elde edilen toplam sayılar tablolarda verilmiştir.

Araştırmada elde edilen veriler araştırmanın güvenirliğini arttırmak amacı ile katılımciların cevaplarından birebir alıntılar yapılarak tema ve kodlar açıklanmaya çalışılmıştır. Kodlamalarda araştırmacının etkisini en aza indirmek için veriler farklı kodlayıcılar tarafından kodlanarak güvenirlik hesaplamaları yapılmıştır. Ayrıca katılımcıların tanımlanması, elde edilen verilerin analizinde kullanılan kavramsal çerçeve ve varsayımların tanımlanması ile veri toplama ve analiz yöntemlerine ilişkin açıklamaların yapılması dış güvenirliğin sağlanmasında alınacak önlemlerdendir (Yıldırım ve Şimşek, 2018). Bu kapsamda, araştırmada veri kaynakları tanımlanmış, benzer araştırma yapan kişilerin veri kaynaklarını belirlemeleri yol gösterici nitelikte olacağı düşünülmüştür. Elde edilen bulguların da literatürle tartışılması teyit edilebilirlik açısından önem taşımaktadır.

\section{Bulgular}

Araştırmanın bu bölümünde, araştırma sonucunda elde edilen bulgular tablolar halinde düzenlenmiş ve doğrudan alıntılar yapılarak özetlenmistir. 


\section{Öğrencilerin Okul Olgunluklarnın Okula Uyum Bakımından Okuma Yazma Sürecine Etkisi}

Öğrencilerin okul olgunluklarının okuma yazma sürecine etkisi ile ilgili öğretmen görüsslerinin analizleri Tablo 2'de verilmiştir.

Tablo 2. Öğrencilerin okul olgunluklarınn okula uyum bakımmdan okuma yazma sürecine etkisi ile ilgili öğretmen görüşleri

\begin{tabular}{ll}
\hline & $(\mathbf{f})$ \\
\hline Olumlu & $\mathbf{2 4}$ \\
\hline Kolay adaptasyon & 7 \\
\hline Yüksek motivasyon & 5 \\
\hline Anasınıfına gitmiş olma & 5 \\
\hline Okula sempati duyma & 4 \\
\hline Güvenli aile ortamında yetişmiş olma & 3 \\
\hline Olumsuz & $\mathbf{3 0}$ \\
\hline Anne, aileden ayrılma sorunu & 6 \\
\hline Duygusal sorunları olan & 6 \\
\hline Okul fobisi & 5 \\
\hline Sorumluluk bilinci olmayan & 5 \\
\hline Aşırı koruyucu ailede yetişme & 4 \\
\hline Ailevi sorunlan olan & 3 \\
\hline Dil becerisi gelişmemiş olması & 1 \\
\hline Toplam & $\mathbf{5 4}$ \\
\hline
\end{tabular}

Tablo 2' de görüldüğü gibi öğretmenlerin, öğrencilerin okul olgunluklarının okula uyum bakımından okuma yazma sürecine etkisi ile ilgili soruya verdiği cevaplar analiz edildiğinde olumlu ve olumsuz kavramlar şeklinde iki grup olarak sınıflandırılmıştır.

Öğretmenler, okul olgunluğu yüksek öğrencilerin okuma yazma sürecinin olumlu yönde etkilendiğini ifade ederken (f:24), aynı zaman okul olgunluğu düşük öğrencilerin okuma yazma sürecinin olumsuz yönde etkilendiğini (f:30) ifade etmişlerdir.

Öğretmenler, okul olgunluğuna erişmiş öğrencilerin okuma yazma sürecine olumlu etkisinin en çok okula daha kolay adapte olmaları (f:7) şeklinde ifade etmişlerdir. Bunun yanı sıra okul olgunluğu yüksek öğrencilerin diğer öğrencilere göre daha yüksek motivasyona sahip olma(f:5), okula sempati duyma (f:3) gibi olumlu etkilerinin oldukların ifade etmişlerdir. Ayrıca öğretmenler okul öncesi eğitim almış olan öğrencilerin okul olgunluklarının 
yüksek olduğunu ve bunun okuma yazma sürecine olumlu etki ettiğini belirtmişlerdir. Aşağıda buna ilişkin bazı öğretmen ifadeleri verilmiştir.

- Ö1: “Okula daha hazır olarak gelen öğrenciler daha kolay uyum sağlıyor, derslere daha iyi motive oluyor, okuma yazmayı daha kolay öğreniyor. Genellikle anasınıfına gitmiş olanlar bu özellikleri sergiliyor."

- Ö3: "Okul olgunluğu gelişmiş bir öğrenci okula daha kolay adapte olabildiği için derslere daha kolay motive oluyor böylelikle öğrenmeye hazır hale geliyor."

- Ö5: "Eğer anasınıfına gitmişse okul olgunluğu kazanmış olarak geliyor, daha kolay motive olup kolay uyum sağlıyor ve okuma yazmayı daha kolay öğreniyor."

- Ö10: “Ailelerin, okula uyum konusunda okul olgunluğu kazanamamış öğrencilerin duygusal olarak yaşadıkları sorunlara yönelik aşırı hassas ve koruyucu davranıp okula devamlılığında kararlı olamamaları ve tam ters tepki olarak, öğrenciyi okula gitmesi konusunda zorlayıcı davranmamaları, öğrencilerin okula karşı tutum ve davranışlarını olumsuz etkilemektedir. Okula karşı sempati duymayan bir öğrenci için okuma yazma öğrenimi daha zor ve istenmeyen bir süreç haline gelmektedir. Bu nedenle okula hazır olmak, okul uyumunu kolaylaştırdığı için okuma yazma öğrenimine geçiş ve uyumda kolay olmaktadır."

- Ö11: "Güvenli bir aile ortamında yetişmiş çocuklar okulda bulunduğu süre içerisinde ailesinden ayrılsa da bu sürenin sonunda ailesine kavuşacağını bilir. Bu da öğrenciye güven vermektedir. Bu da öğrencinin okuldaki kaygı düzeyini düşürecektir. Kaygı düzeyi düşük olan öğrenciler ilgi ve dikkatini okuma yazma süreçlerine verecek ve okuma yazma becerisine hızlı ve başarılı bir şekilde gerçekleştirecektir."

- Ö13: "Okul olgunluğuna ulaşmış öğrenciler okula gelmekten korkmuyor, okulu daha kolay sevip, benimsiyor. Zaten okula karşı bir sempati duyarak geliyor ve kolay adapte oluyor. Bu yüzden daha kolay okuma yazma sürecini tamamlıyor."

Sınıf öğretmelerinden okul olgunlukları düşük öğrencilerin okula uyum bakımından okuma yazma sürecinin olumsuz (f:30) etkilendiğini ifade edenler bunun nedeni olarak aşırı koruyucu ailelerde yetişmiş olma (f:6), duygusal sorunlar (f:6) ve anneden ayrılma korkusu (f:6) olduğunu belirtmişlerdir. 
Bunun yanı sıra diğer etkenleri okul fobisi (f:5), gelişmemiş sorumluluk duygusu (f:5), ailevi sorunlar (f:3), gelişmemiş dil becerisi (f:1) şeklinde ifade etmişlerdir. Bu cevapları veren bazı öğretmenlerin ifadeleri şöyledir:

- Ö4: “Öğrencilerden bazıları okula uyum sürecinde sıkıntılar yaşayabiliyor. Özellikle ilk haftalarda yanı başında derste anne babası olsun istiyor, ağlıyor. Bu gibi durumlar okula uyum sürecini, dolayısıyla okuma yazma sürecini olumsuz etkiliyor."

- Ö5: “Aileden ayrılma problemi olan çocuklar zor öğrenmekte.”

- Ö7: “Öğrenciler okula gelirken zihni evde anne babada kaldığı zaman en başta okula uyum konusunda problem yaşıyor. İçine kapanık sürekli ağlamaya meyilli öğretime kapalı olarak karşımıza çıkıyor."

- Ö9: “Şayet veli çocuğuna yeteri kadar kendini tanıyabilme, bir şeyleri başarabilme ile ilgili sorumluluk bilinci kazandırmadı ise ya da hiç yalnız bırakmadı ise çocuğun okuma yazma öğrenmesinde sıkıntı olabiliyor."

- Ö10: "Okul olgunluğu kazanmış bir öğrenci, bu konuda yeterince hazır olmayan öğrencilere göre, kendisi için yeni ve farklı bir ortam olan okula ve okul kurallarına hızlı şekilde uyum göstermektedir. Aksi durumda ortaya çıkan okulun ilk günleri anneden ayrılmak istememe, korkma, endişe duyma, güvensizlik hissetme gibi duygusal sorunların yaşanması, bulunduğu sınıfı bulamama, yanlış alanlara girip kaybolma ve çaresiz hissetme, sürekli öğretmenin ya da varsa üst sinıflarda okuyan tanıdı̆̆ 1 bir öğrencinin yanında kalmayı isteme gibi davranışlar öğrencinin okula uyum sürecini fazlasıyla uzatmakta ve çözümlenmediği sürece de okuma yazma gibi önemli bir bilişsel süreç öğrenci için gecikmektedir."

- Ö11: “Okulu bir korku ve tehdit aracı olarak kullanan velilerin öğrencileri okula karşı önyargılı yaklaşmakta okula uyumu reddetmektedir. Okulu kaygı ve korkunun merkezi olarak gören öğrenciler okuma yazma süreçlerinde başarılı olamamaktadır."

\section{Öğrencilerin Okul Olgunluklarının Motor Gelişim Bakımından Okuma Yazma Sürecine Etkisi}

Öğrencilerin okul olgunluklarının motor gelişim bakımından okuma yazma sürecine etkisine ilişkin bulgular Tablo 3'te belirtilmiştir. 
Tablo 3. Öğrencilerin okul olgunluklarının motor gelişim bakımından okuma yazma sürecine etkisi ile ilgili öğretmen görüşleri

\begin{tabular}{ll}
\hline Olumlu & 31 \\
\hline Anasınıfına gitmiş olma & 7 \\
\hline Doğru kalem tutma & 5 \\
\hline Yazı yönünü doğru yapma & 4 \\
\hline Çizgileri takip etme & 4 \\
\hline Özgüveni yüksek olma & 3 \\
\hline Kitapla tanışmış olma & 3 \\
\hline Kelimeler arası boşluk bırakma & 3 \\
\hline Sırada oturma & 2 \\
\hline Olumsuz & $\mathbf{1 6}$ \\
\hline Çabuk sıkılma & 4 \\
\hline Motive olamama & 4 \\
\hline Dikkat dağınıklığı & 3 \\
\hline Düzensiz yazma & 3 \\
\hline Sirada oturamama & 2 \\
\hline Toplam & $\mathbf{4 7}$ \\
\hline
\end{tabular}

Tablo 3'te öğretmenlerin, öğrencilerin okul olgunluklarının motor gelişim bakımından okuma yazma sürecine etkisi ile ilgili soruya verdiği cevaplar görülmektedir. Öğretmenlerin, öğrencilerin okul olgunluklarının motor gelişim bakımından okuma yazma sürecine etkisi ile ilgili soruya verdiği cevaplar analiz edilerek, olumlu ve olumsuz kavramlar şeklinde iki grup olarak sinıflandırılmıştır.

Öğretmenler öğrencilerin motor gelişim açısından okul olgunluğu yüksek olanların okuma yazma sürecinin olumlu yönde (f: 31 ) etkilendiğini ifade etmişlerdir. Bu olumlu etkinin nedenlerini ise anasınıfına gitmiş olma (f:7), kalemi doğru tutma (f:5), çizgileri takip etme (f:4), yazı yönünü doğru yazma (f:4), özgüveni yüksek olma (f:3), kitapla tanışış olma (f:3), sırada oturma (f:2) gibi becerileri gelişmiş öğrencilerin okuma yazma sürecinde daha başarılı olduklarını ifade etmişlerdir. Ayrıca öğretmenler, öğrencilerin içinde bulundukları yaşın kaçıncı ayında olduklarının motor beceri düzeylerini ve bu sebeple okuma yazma sürecini etkilediğini ifade etmişlerdir. Aşağıda öğretmenlerin bu görüşlerini ifade ettikleri cevaplardan bazıları verilmiştir.

- Ö1: “Genelde anaokuluna gitmiş öğrenciler motor becerileri gelişmiş olarak okula başlıyor. Bu durum onların okuma yazma sürecini olumlu etkiliyor. Harfleri doğru yönde başlatıp bitiriyorlar, defterde çizgilerin arasına daha kolay yazıyorlar yani özellikle yazma becerilerini kolay kazaniyorlar." 
- Ö3: “Okuma yazmaya hazırlık sürecinde özellikle, okul öncesi eğitimi almış, okul olgunluğuna erişmiş çocuklarda düzenli ve düzensiz çizgilerin yazımında olumlu yönde etkisini görüyoruz. Yazarken çizgiler, yazım yönleri daha düzgün oluyor."

- Ö5: “Çocuk, başardıkça özgüveni yerine gelir istekli olur. Okula başlayan çocuğun,kalem tutmayı becerebilmesi, okuma yazmaya hazırlık çizgilerini doğru çekmesi bile onu, okuma yazma sürecinde başarılı ve istekli k1liyor."

- Ö8: “Olgunluk düzeyi yüksek öğrenci okula geldiğinde ilk karşılaştığ1 çizgi çalışmaları, boyama çalışmaları gibi etkinlikleri kolaylıkla tamamlıyor. Böylece okulda başarısızlık duygusuna kapılmıyor, özgüveni yüksek oluyor ve okuma yazmada da başarılı oluyor."

- Ö10: “Kitapla tanışma, kalem tutma, makas kullanma, hamur oyunları, fiziksel oyunlar vb. etkinlikleri yapmış olan ve okul öncesi eğitimi alarak bu becerilerini daha da geliştirme fırsatı bulan öğrenciler okuma yazma sürecinde kalem tutma, sırada düzenli oturma, defter kullanımı, çizgileri takip edebilme vb. motor becerilerde zorluk yaşamamaktadır. Bu durum okuma yazma sürecinin daha rahat başlamasını ve verimli şekilde ilerlemesini sağlamaktadır."

Ayrıca öğretmenler motor gelişim düzeyi düşük olan öğrencilerin okuma yazma sürecinin olumsuz yönde etkilendiğini (f:16) ifade etmişlerdir. Öğretmenler motor gelişim düzeyi düşük öğrencilerin çabuk s1kılma (f:4), motive olamama (f:4), dikkat dağınıklığı (f:3), düzensiz yazma (f:3) ve sirada oturamama (f:2) gibi nedenlerle okuma yazma sürecinin olumsuz etkilendiğini belirtmişlerdir. Aşağıda öğretmenlerin bu görüşlerini ifade ettikleri cevaplardan bazıları verilmiştir.

- Ö2: “Kalem tutma olsun, sirada oturma süresi olsun yazmaya hazırlık çalışmaları olsun yeterli tecrübeleri ya da kendilerine yol gösterici birileri olmadığından diğer çocuklara oranla hep geç öğreniyorlar."

- Ö4: “Okuma yazma öğrenirken kalem, defter, kitap vb. araçlarla ilk kez okulda karşılaşan öğrencilerde okuma yazmaya uyum süreci zor ve gecikmeli olmaktadır. Öğrenci zorlandıkça yapamadığını düşünmekte, motive olamamakta, çalışmayı yapmayı reddetmektedir." 
- Ö7: “Motor becerilerde yaşanan bu zorluk çabuk yorulmalarına ve çalışmayı eksik bırakmalarına yol açmaktadır. Okuma yazma sürecinde düzenli ve okunaklı yazı yazma, defter düzeni oluşturma gibi becerileri de olumsuz etkileyebilmektedir."

- Ö12: “Aileden ayrı kalmak, bilmediği bir ortamda okuma yazma gibi yüksek düzeyde algılamasını gerektiren durumlarda daha da çok zorlanmalarına, yaşları küçük olan çocukların özellikle kas gelişimi ve motor becerileri yeterli seviyede de olmadığı için bu kaygılar başarısızlıkla birleşerek bu süreci diğerlerinden daha geç tamamlamalarına, yazmada isteksizliğe sebep olmaktadır."

- Ö13: “Okuma ve yazma süreci oldukça meşakkatli bir süreç, bu süreç için çocuk yeterince olgunlaşmamış ise sırasında düzgün oturamıyor, rahat edemiyor, motivasyonu aşırı düşük oluyor ve tabi zor öğreniyor."

- Ö14: “Çocuğun olgunluk düzeyi düşükse çok çabuk sıkılıyor, dikkatini veremiyor, sıkıldığı için hemen yapıp bitirmek istiyor bu yüzden düzgün ve doğru yazamıyor."

\section{Öğrencilerin Okul Olgunluklarının Sosyal Beceriler Bakımından Okuma} Yazma Sürecine Etkisi

Öğrencilerin okul olgunluklarının sosyal beceriler bakımından okuma yazma sürecine etkisine ilişkin bulgular Tablo 4'te yer almaktadır.

Tablo 4. Öğrencilerin okul olgunluklarının sosyal beceriler bakımından okuma yazma sürecine etkisi ile ilgili öğretmen görüşleri

\begin{tabular}{ll}
\hline Olumlu & 25 \\
\hline Çevresi ile iletişimi iyi olan & 8 \\
\hline Kendini ifade etme becerisi yüksek olma & 6 \\
\hline Özgüveni yüksek olma & 4 \\
\hline Kolay motivasyon & 4 \\
\hline Okulun çekici gelmesi & 3 \\
\hline Olumsuz & $\mathbf{1 8}$ \\
\hline İletişim kopukluğu yaşayan & 7 \\
\hline Özgüven eksikliği & 5 \\
\hline Çekingen, içine kapanıklık & 3 \\
\hline Gruba dâhil olamama & 3 \\
\hline Toplam & $\mathbf{4 3}$ \\
\hline
\end{tabular}


Tablo 4'te öğretmenlerin, öğrencilerin okul olgunluklarının sosyal beceriler bakımından okuma yazma sürecine etkisi ile ilgili soruya verdiği cevaplar görülmektedir. Bu soruya öğretmenlerin verdiği cevaplar, olumlu etkiler (f:25) ve olumsuz etkiler (f:18) şeklinde gruplanmıştır.

Öğretmenler okul olgunluğu yüksek öğrencilerin çevresi ile iletişimleri güçlü (f:8), kendini ifade etme becerileri yüksek (f:6), kolay motive olan (f:4), özgüveni yüksek (f:4) ve okulu çekici bulan (f:3) öğrenciler olduklarını ifade etmişlerdir. Öğretmenler bu özelliklere sahip öğrencilerin sosyal beceriler bakımından güçlü ve okuma yazma süreçlerinin daha başarılı geçiren öğrenciler olduğunu belirtmişlerdir. Bu görüşü destekleyen öğretmen ifadelerinden bazıları şu şekildedir:

- Ö3: “Okul olgunluğu olumlu yönde gelişmiş öğrenci, öğretmenine ve arkadaşlarına daha kolay uyum sağlıyor. Öğretmenine, böylelikle derslere daha ilgili olduğu için daha hızlı bir öğrenme gerçekleştiriyor."

- Ö6: "Okul olgunluğu gelişmiş öğrencilerin arkadaşlarıyla iletişiminde sıkıntı olmamakta. Arkadaşlarıyla ilişkilerinde olumlu tutum ve davranışlara sahip öğrenciler çok daha rahat öğreniyor. Akran öğretiminin okuma yazma sürecinde olumlu etkisi var."

- Ö10: “Okul olgunluğuna sahip öğrenciler bu yeni ortamda tanıştığ1 kişileri merak eder, tanımaya çalışır, iletişime açıktır. Kendini tanıtabilir, ifade edebilir, duygularını ve düşüncelerini paylaşmaktan çekinmez. Arkadaşlarıyla oyunlara katılır, bundan keyif alır, öğretmeniyle iletişim halinde olmayı, kendisine yönelik olumlu tepkiler almayı ister. Bu konuda oluşan bu sağlıklı iletişim, öğrenme sürecinde de olumlu etkiler yaratır. Okuma yazma sürecinde zorlandığı yerde yardım ister, anlamadığı yerlerde çekinmeden sorar, okuma yazma çalışması yaparken yanlış yapmaktan korkmaz. Arkadaşlarıyla birlikte çalışmalar yapmaya istek duyar."

- Ö11: "Belirli bir olgunluğa erişmiş öğrencinin kendini güveni yerinde olacaktır. Kendine güveni olan ve dilsel becerileri gelişmiş öğrenciler çevresi ile daha iyi iletişim kurmaktadır. İletişimi iyi olan öğrenciler istek ve sorunlarını öğretmen ve arkadaşlarına doğru şekilde ifade edebilecektir. Okuma yazma süreçlerinde anlayamadığı yerleri öğretmenine ve arkadaşlarına sormaktan çekinmeyecektir. Sosyal becerileri gelişmiş 
öğrenciler arkadaşlarının okuma yazma süreçlerine de destek olmaktadır. Akran öğretiminde önemli görevler alıp öğretmene yardımcı olmaktadır."

Öğretmenler okul olgunluğu kazanmamış öğrencilerin sosyal beceriler bakımından iletişim kopukluğu (f:7), özgüven eksikliği (f:5), gruba dâhil olamama (f:3) ve içine kapanıklık (f:3) gibi nedenlerden dolayı sınıf içinde okuma yazma sürecine etkin katılım gösteremediğini ve okuma yazma öğrenme sürecinin bu nedenlerden olumsuz etkilendiğini ifade etmişlerdir. Bu görüssleri bildiren bazı öğretmenlerin cevapları şöyledir:

- Ö1: “Bu grup öğrencilerde yaşadığımız en temel sıkıntı arkadaşları ile iletişiminden ziyade öğretmenleri ile olan ilişkilerde kopukluk olması. Ne yazık ki aradaki dil farkı bu olgunluğu kazanamamış öğrencilerde özellikle öğretmeni ile sosyal ilişki kuramamasına neden oluyor. Öğretmeni anlamadığı için okuma yazma sürecine de etkin bir şekilde katılamiyor."

- Ö5: “Okul olgunluğu kazanmamış öğrenciler okula başladığında ne arkadaşıyla ne öğretmeniyle ne de okul çalışanıyla iletişime geçiyor. Derdini söyleyemiyor, öğretmenini anlamasa anlamadım diyemiyor. Arkadaşlarına ben de oynamak istiyorum diyemiyor. Arkadaşlarıyla bir olamiyor. Kendini sınıfına okuluna ait hissetmiyor. Bu yüzden okuldan uzaklaşıyor derslerden soğuyor. Okuma yazmayı da geç öğreniyor."

- Ö10: "İletişim konusunda kendini açmayan, bu konuda gerekli okul olgunluğu edinememiş öğrencilerde sinıf içinde kendini ait hissetmeme, çekingen davranma, yalnız kalma, gruba dahil olamama, kendini ifade edememe ve özgüvensizlik duyma gibi sorunlar görülebilmektedir. Okuma yazma sürecinde zorlandığı anlarda iletişim kuramaması çözüm bulmasını zorlaştırmaktadır. Arkadaşları ve öğretmeni ile birlikte bir sınıfın üyesi olma hissini yaşamayan öğrenciler için bu alanda yapılan çalışma ve öğrenme süreçleri de anlamlı ve istek uyandırıcı olamamaktadır."

- Ö11: “İçine kapanık, sosyal becerisi gelişmemiş öğrenciler anlayamadığı yerleri sormakta çekinmektedir. Okuma yazma süreçlerinin büyük bir bölümü konuşma ve etkin dinlemeyle öğrenebilecek becerilerdir. İletişim becerisi iyi olan öğrenci öğretmenin anlattıklarını etkin bir şekilde dinlemektedir. $\mathrm{Bu}$ da okuma yazma süreçlerinin huzlı bir şekilde kavranmasını sağlamaktadır." 


\section{Öğrencilerin Okul Olgunluklarının Kurallara Uyma Bakımından Okuma Yazma Sürecine Etkisi}

Öğrencilerin okul olgunluklarının kurallara uyma bakımından okuma yazma sürecine etkisine ilişkin bulgular Tablo 5 'te yer almaktadır.

Tablo 5. Öğrencilerin okul olgunluklarının kurallara uyma bakımından okuma yazma sü-

\begin{tabular}{ll}
\hline recine etkisi ile ilgili öğretmen görüşleri & $(\boldsymbol{f})$ \\
\hline Olumlu & 28 \\
\hline Kuralları kolay benimser & 5 \\
\hline Yönergeleri kolay takip etme & 5 \\
\hline Sinıf düzenini bozmama & 4 \\
\hline Sorumluluk bilinci hizlı gelişir & 4 \\
\hline Planlı çalışma & 4 \\
\hline Uyumsuzluk yaşamama & 3 \\
\hline Derse hazırlıklıglme & 3 \\
\hline Olumsuz & 3 \\
\hline İstenmedik davranışlarda bulunma & 3 \\
\hline Etkisi yoktur & 1 \\
\hline Toplam & 32 \\
\hline
\end{tabular}

Tablo 5'te öğrencilerin okul olgunluklarının, kurallara uyma bakımından okuma yazma sürecine etkisi ile ilgili soruya öğretmenlerin verdiği cevaplar görülmektedir. Bu soruya öğretmenlerin verdiği cevaplar olumlu etkiler, olumsuz etkiler ve etkisi yoktur şeklinde gruplanmıştır.

Öğretmenler, öğrencilerin okul olgunluklarının kurallara uyma bakımından okuma yazmaya olumlu etkilerini kuralları kolay benimseme (f:5) , yönergeleri takip edebilme (f:5), planlı çalışma (f:4), sınıf düzenini bozmama (f:4) ve uyumsuzluk yaşamama (f:3) şeklinde ifade etmişlerdir. Öğretmenlerin öğrencilerde gelişmiş kural bilincinin ödevleri zamanında ve düzenli yapma, derse hazırlıklı gelme, sınıf içindeki kurallara uyarak istenmeyen davranış sergilememe gibi davranışları kolaylıkla kabullenmelerinin okuma yazma sürecini hızlandırdığını ifade ettikleri görülmüştür. Bu görüşü destekleyen bazı öğretmen ifadeleri aşağıda verilmiştir.

- Ö1: “Olgunluğa sahip öğrenciler kuralları çok daha kolay benimseyip bunu zorunluluk olarak görmek yerine isteyerek uyguluyorlar. Öğrencilerin mutluluğu okuma yazma öğrenme sürecine olumlu yansıyor." 
- Ö3: “Okul olgunluğu gelişmiş bir öğrenci özellikle anasınıfına gitmiş bir öğrenci sınıfta hangi kuralları takip etmesi gerektiğini daha hızlı benimsemekte böylece uyumsuzluk yaşamadığı için derslere odaklanabilmektedir."

- Ö4: “Okul olgunluğuna erişmiş çocuklar kendilerini daha rahat ifade edebildikleri için okuma yazma sürecinde sınıf içi kurallar oluşturmaya katkı sağlıyorlar, verilen görevleri daha çabuk anlıyor ve yerine getiriyorlar, sorumluluk bilinciyle okuma yazma süreci daha rahat ve kendiliğinden gelişiveriyor."

- Ö7: “Okul giriş çıkış saatlerine beslenme saatine öğretmen tarafından verilen yönergelere uyması çocuğun okul olgunluğuna ulaştığının önemli göstergesidir. Okuma yazma sürecinde belki de en önemli etken çocuğun sorumluluğunu bilmesi verilen yönergelere uyması onun okuma yazma geçişini hızlandıracaktır."

- Ö10: "Okuma ve yazma öğrenimi ciddi ve dikkat edilmesi gereken bir süreçtir. Bu süreçte yaşanan bir sıkıntı ya da gecikme sonraki öğrenmeleri önemli ölçüde etkilediği için öğrencilerin bu sürece uygun şekilde katılmaları, çalışmaları düzenli ve zamanında gerçekleştirmeleri, araç gereç hazırlı̆̆ından, ödev yapma, tekrar etme gibi davranışları edinmeleri gerekli durumlardır. Okul ile başlayan bu kurallar ve sorumluluklar öğrenciler tarafından kabullenilmesi ve yerine getirilmesi için okul olgunluğu gereklidir."

- Ö11: “Çocukların kuralları sevmediği düşünülse de çocukların kuralları sevdiğini düşünüyorum. Çocuklar için az kural öz kural olmalıdır. Ev ortamında belirli kurallara uyup okula gelen öğrenciler, okuldaki kurallara uymakta zorlanmamakta, sınıf ve okul düzenini bozmamaktadır. Evde kitap okunmuş, belirli görevler verilmiş ya da etkinlik yapılmış öğrencilerin yönergelere uyması, yapmayanlara göre daha kolaydır. Okuma yazma süreçlerinde öğretmen, belirli bölümlerde yönergeler vermekte ve öğrencinin bazı işlemleri yapmasını istemektedir. Öğretmenin vermiş olduğu yönergeyi doğru anlayıp gerçekleştiren öğrenciler, okuma yazma konusunda daha başarılı olmaktadır."

Öğretmenler öğrencilerin okul olgunluklarının kurallara uyma bakıminda okuma yazmaya olumsuz etkilerine istenmeyen davranışlar sergileme 
(f:3) gibi nedenlerle okuma yazma sürecine adapte olamadıkları için bu sürecin olumsuz etkilediğini belirtmişlerdir. Bu durumu ifade eden bazı öğretmen görüşleri şu şekildedir.

- Ö10: “Bu konuda hazır olmayan öğrenciler için okuma yazma öğrenimi zor, yorucu gelmekte, derse hazırlıklı gelmek, ders yönergelerine uymak, ödev yapma alışkanlığı ve sorumluluğu kazanmak kolay olmamaktadır. Bu konuda yaşanan sıkıntılar, okuma yazma sürecinin düzenli ve verimli ilerlemesini engellemektedir. Ayrıca sınıf içinde kurallara uymama, gürültü yapma, ders dinlememe, ders araç gereçlerini hazırlamama, yazı yazmama vb. durumlar sağlıklı bir öğrenme ortamını ve sürecini aksatmaktadır."

- Ö11: “Evde kuralları olmayan çocuklar, okulun da kuralları olmayan bir yer olduğunu düşünmektedir. Sınıf ortamında kurallara uyulmaması sınufta bir kargaşa ve düzensizlik ortamı oluşturmaktadır. Kargaşa ortaminda anlatilan konunun kavranması ve okuma yazma becerilerinin kazanılması mümkün değildir."

- Ö13: “Çocuklar kurallara uyması gerektiğini anlayacak olgunlukta değilken okula başladıklarında sınıf içinde istenmeyen davranışlar gösteriyorlar. Örneğin, ders esnasında öğretmenini dinlemesi gerektiğini kabullenmiyor ve arkadaşlarıyla konuşuyor. Dersi dinlemediği için de geri kalıyor."

Bu soruya Ö8 olarak tanımlanan öğretmen, okul olgunluğunun kurallara uyma bakımından bir etkisi olmadığını dolayısıyla bu durumun okuma yazma sürecine de etkisinin bulunmadığını ifade etmiştir. Bu öğretmenin görüşü aşağıda verilmiştir.

Ö8: "Öğretmenler okulun ilk aylarında belli kuralları kavratırlar, böylece okuma yazma sürecinde sıkıntı ortadan kaldırılmaktadır."

\section{Öğrencilerin Okul Olgunluklarının Öz Bakım Becerileri Bakımından Okuma Yazma Sürecine Etkisi}

Öğrencilerin okul olgunluklarının öz bakım becerileri bakımından okuma yazma sürecine etkisine ilişkin bulgular Tablo 6' da verilmiştir. 
Tablo 6. Öğrencilerin okul olgunluklarının öz bakım becerileri bakımından okuma yazma sürecine etkisi ile ilgili öğretmen görüşleri

\begin{tabular}{ll}
\hline & $(\mathbf{f})$ \\
\hline Olumlu & $\mathbf{1 4}$ \\
\hline Daha yüksek özgüven & 6 \\
\hline Doğru, rahat iletişim kurma & 3 \\
\hline Bölünmeyen ders & 3 \\
\hline Daha düzenli yazma becerisi & 2 \\
\hline Olumsuz & $\mathbf{2 5}$ \\
\hline Düşük adaptasyon & 5 \\
\hline Okuldan uzaklaşma & 5 \\
\hline Öğretmene yaklaşmak istememesi & 4 \\
\hline Derslerin bölünmesine sebep olma & 3 \\
\hline Düşük özgüven & 3 \\
\hline Temiz olmamaktan utanma & 3 \\
\hline Doğru beslenememe & 2 \\
\hline Toplam & $\mathbf{3 9}$ \\
\hline
\end{tabular}

Tablo 6'da öğrencilerin okul olgunluklarının öz bakım becerileri bakımından okuma yazma sürecine etkisi ile ilgili soruya öğretmenlerin verdiği cevaplar görülmektedir. Bu soruya öğretmenlerin verdiği cevaplar olumlu etkiler (f:14) ve olumsuz etkiler (f:25) şeklinde gruplanmıştr.

Öğretmen görüşlerine göre okul olgunluğunu kazanmış öğrencilerin öz bakım becerilerinin gelişmiş olduğu belirtilmiştir. Öğretmenler öz bakım becerilerine sahip bir öğrencinin daha yüksek özgüvene sahip olma (f:6), doğru rahat iletişim kurabilme (f:3), dersleri bütün bir şekilde takip edebilme (f:3) ve daha düzenli yazma becerisine sahip olma (f:2) gibi okuma yazma sürecine olumlu etki sağlayacak becerileri etkilediğini belirtmişlerdir. Bu soruya öğretmenlerin verdiği cevaplardan bazıları şunlardır:

- Ö3: “Öz bakım becerilerini geliştirmiş bir öğrenci, derslerde daha az bölünme yaşıyor. Dersi takip etmesi bölünmediği için okuma yazmayı bölünene göre daha kolay ve çabuk öğreniyor."

- Ö4: “Defter düzeni ve temizliği, yazmadaki özeni olumlu yönde etkiliyor."

- Ö9: “Tuvalet, beslenme gibi ihtiyaçlarını kendi başına gideren çocuğun kendine öz güveni yüksek oluyor. Tabii ki bu özgüven, okuma yazma öğrenmesine olumlu katkılar sağlıyor."

- Ö14: “Öz bakımını yapabilen çocuk, temiz olduğu için rahat hareket ediyor, çekinmiyor, kendini ifade edebiliyor okulda yaşadığı tüm süreçler gibi okuma yazma süreci de bundan olumlu etkileniyor." 
Gelişmiş öz bakım becerisine sahip olmayan çocukların yeterli okul olgunluğunu kazanmamış olduğunu belirten öğretmenler bu durumun, öğrencilerin düşük adaptasyon (f:5), okuldan uzaklaşma (f:5), öğretmene yaklaşmak istememe (f:4), derslerin bölünmesi (f:3), yeterince temiz olamama (f:3), düşük özgüven (f:3) ve doğru beslenememe (f:2) gibi olumsuzluklar yaşadıklarını ve bu durumun okuma yazma sürecini etkilediğini ifade etmişlerdir. Bu görüşü destekleyen bazı öğretmen cevapları şöyledir:

- Ö1: “Tüm birinci sınıf öğrencilerinde karşılaştığımız temel sorun tuvalet ve zamanı etkin kullanamama. Özellikle ders esnasında sürekli tuvaleti gelen öğrencilerimiz oluyor. İzin vermek zorundayız fakat çocuk o bölünmeden sonra tekrar motivasyonunu toplamakta zorluk yaşıyor."

- Ö6: “Öz bakım becerilerini geliştiremeyen çocukların özgüvenleri de düşük oluyor, dolayısıyla okuma yazma da başarısız oluyorlar."

- Ö10: "Tuvalete gittiğinde alanı düzgün kullanamayan, kıyafetlerini düzeltemeyen, üzerine sslatma gibi sorunlar yaşayan öğrenciler öncelikle duygusal olarak etkilenmektedir. Böyle bir durum yaşayan öğrenciler ya utanmakta ve yardım istemekten çekinmekte ya da arkadaşları tarafından eleştirilince, ağlayıp eve gitmek, okuldan ayrılmak istemektedir. Temizlik kurallarına uymayan, el yıkama, kıyafetlerini temiz tutma, kişisel bakım konularında gerekli becerileri sergilemeyen öğrenciler hem öğretmen hem de öğrenciler için rahatsızlık verici olmaktadır. Beslenme konusunda kurallara uygun yemek yememek, görgü kurallarına uymamak benzer şekilde öğrencinin çevresinden tepki görmesine yol açmaktadır. Tüm bu öz bakım yönünden okula hazır olmama durumu sınıf içindeki okuma yazma sürecini olumsuz etkilemektedir."

- Ö11: "Elleri kirli, tırnakları uzun öğrenciler yazma işleminde rahat edememekte, ellerini ya da trnaklarını arkadaşlarını görmemesi için hizlıca yazmaktadır. Rahat edemeyen ve hızlıca yazan öğrencilerin yazma başarıları düşük olmaktadır."

\section{Tartışma, Sonuç ve Öneriler}

Bu çalışmada birinci sınıfa başlayan öğrencilerin okul olgunluklarının okuma yazma sürecine etkisi, öğretmen görüşlerine göre incelenmiştir. Elde edilen bulgular ışı̆̆ında şu sonuçlara ulaşılmıştır: 
Öğrencilerin okul olgunluklarının, okula uyum bakımından okuma yazma sürecini etkilediği, okul olgunluğu düşük öğrencilerin özellikle aileden ayrılmak istememe, okuldan korkma, ailede yaşanılan sorunlar ve aşırı koruyucu ailelerde yetişmiş olma gibi durumları okula uyum sürecini yavaşlattığı için okuma yazma sürecini olumsuz etkilediği sonuçlarına ulaşılmıştır. Ayrıca okul olgunluğu kazanmış öğrencilerin okula karşı sempati duymaları, okul ortamına kolay adapte olmaları ve okula karşı yüksek motivasyona sahip olmalarının okuma yazma sürecini olumlu etkilediği sonucuna ulaşılmıştır.

Alan yazında, çalışmamız sonuçları ile benzerlik gösteren çalışmalar yeralmaktadır. Erbasan ve Erbasan (2019) çalışmasında, hazır bulunuşluk düzeyleri okuma yazma öğretimi için uygun olmayan öğrencilerde okula uyum sağlayamama, kalem tutamama, öz bakım becerilerini tam olarak yerine getirememe ve derslerden çabuk sıkılma gibi çeşitli sorunlarla karşılaşıldığ 1 sonucuna ulaşılmıştır. Güler (2016) çalışmasında ise, öğrencilerin okula başlama yaşı ilerledikçe hazır bulunuşlukları ve böylece okula uyum düzeyleri ve okuma yazma becerileri ölçeklerinden aldıkları puanların arttı̆ı sonucuna ulaşılmıştır. Aynı çalışmada okula uyum sürecinde okul öncesi eğitim almış olmanın okuma yazma sürecini etkilediği sonucunada ulaşılmıştır. Yoleri ve Tanış (2014) çalışmasında ise ilköğretim öncesinde, okul öncesi eğitim alan öğrencilerin uyum düzeylerinin almayanlara göre yüksek olduğunu tespit etmişlerdir. Yapılan araştırmalar incelendiğinde okul öncesi eğitimin okula uyumu ve okuma yazma sürecini etkilediğini destekler benzer sonuçlara ulaşıldığı görülmektedir (Ekinci, 2001; Kaytaz, 2005; Pehlivan, 2006; Oktay, 2005).

Araştırma bulgularından ulaşılan sonuçlardan biri de; motor gelişim bakımından okul olgunluğu düzeyleri yüksek olan öğrencilerin kalemi doğru tutma, çizgileri takip etme, sırada oturma, yazı yönünü doğru yazma gibi becerilerinin daha gelişmiş olmasının öğrencilerin okuma yazma sürecinde daha başarılı olmalarına etki ettiği sonucudur. Bunun yanı sıra, motor gelişimi yüksek olan öğrencilerin özgüveninin yüksek olmasına fayda sağladığı ve kitapla tanışmış olmanın göz koordinasyonuna olumlu etki ettiği sonucuna varılmıştır. Ayrıca, anasınıfına gitmiş olma durumunun ve öğrencilerin içinde bulundukları yaşın kaçıncı ayında olduklarının motor beceri düzeylerini dolayısıyla da okuma yazma sürecini etkilemekte olduğu sonucuna ulaşılmıştır. Çalışma sonuçlarımız ile benzerlik gösteren Bozgün ve 
Sağır (2018) çalışmalarında, okul öncesi eğitim almış öğrencilerin bilişsel, duyuşsal ve psikomotor beceriler bakımından daha yüksek hazır bulunuşluk düzeylerinin olduğu ve çizgi çalışmaları, örüntü kurma, dinleme ve ses çalışmalarını okul öncesi eğitimde alan öğrencilerin okuma yazma sürecine daha hızlı adapte olduklarını belirtmişlerdir. Özcan ve Özcan (2016), öğrencilerin motor gelişimiyle ilgili olan kalem tutma ve görsel algılarının gelişmemiş olmasından kaynaklanan satır kavramına sahip olamama gibi sorunlar yaşamalarının yazmayı öğrenme sürecine olumsuz etki ettiği sonucuna ulaşmışlardır. Çökük (2019), okula hazır bulunuşluk olgusunu incelediği çalışmasında farklı yaş aralığındaki çocukların aynı sınıfta bulunmalarının psikomotor becerilerden kalem tutma ve çizgi çalışması gibi etkinliklerde farklılık gösterdiğini belirtmiştir. Vatansever-Bayraktar ve Kendirci (2018), ilkokul birinci sınıf öğrencilerinin okula hazır bulunuşluk düzeylerinin incelenmesi isimli çalışmalarında, ilkokul birinci sınıf öğrencilerinin okula hazır bulunuşluk düzeylerini duyuşsal beceriler, psikomotor beceriler, öz bakım becerileri ve bilişsel becerilerin alt boyutları ile incelemişler ve 72 ay ve üstü olan öğrencilerin okula hazırbulunuşluk düzeylerinin daha yüksek olduğu, bunu 66-71 ay arası ve 60-65 ay arası olan öğrencilerin izlediği sonucuna ulaşmışlardır. Aynı çalışmada öğrencilerin hazır bulunuşluk düzeyleri bakımından okul öncesi eğitim alan öğrenciler lehine anlamlı bir fark olduğu sonucuna varmışladır. Gündüz ve Çalışkan (2013), 60-66, 66-72, 72-84 aylık çocukların okul olgunluk ve okuma yazma becerilerini kazanma düzeylerinin incelenmesi isimli çalışmalarında, öğrencilerin yaş gruplarına göre okul olgunlukları düzeylerini incelemişler ve okul olgunluk düzeyi düşük olan yaş gruplarının okuma yazma sürecinde kavrama güçlüğü, parmak kas gelişimi yetersizliği, yavaş öğrenme, çabuk yorulma ve kurallara uymada bazı güçlükler yaşadıkları sonucuna ulaşmışlardır.

Araştırma sonuçlarından bir diğeri ise, sosyal beceriler açısından okul olgunluğu kazanmış öğrenciler, kendilerini ifade etmekte zorluk çekmedikleri için ders esnasında yaşadıkları sıkıntıları dile getirmekte çekinmemekte, anlamadıkları yerleri sorabilmekte, arkadaşları ve öğretmenleriyle iletişim kurmakta zorlanmamaktadırlar. Bu durum öğrencinin okuma yazma sürecine etkin katılım sağlamasına, süreç esnasında eksiklerini tamamlamasına ve böylece süreçte başarılı olmasına olumlu etki etmektedir. Sosyal beceriler açısından okul olgunluğu düzeyine erişememiş öğrenciler ise, özgüven problemi yaşamakta, soru sormakta çekinmekte, grubun gerisinde kalmakta 
ve arkadaşlarıyla iletişime geçmekte zorlandıkları için gruba dâhil olmadıklarını hissetmektedirler. Bu durumun öğrencilerin okuma yazma sürecinde geri kalmalarına sebep olduğu sonucuna ulaşılmıştır. Buna benzer olarak Babayiğit ve Erkuş (2016), okul olgunluğuna ulaşmamış çocuklarda başaramama kaygısı, beğenilmeme korkusu, geçmiş yaşant eksikliklerinden ya da olumsuzluklarından kaynaklanan, kendine olan güvensizlik gibi nedenlerin okuma yazma öğrenme sürecini olumsuz etkileyerek, gecikmelere neden olduğu sonucuna varmışlardır. Bunun yanı sıra sorumluluk duygusu gelişmemiş öğrencilerin okula başladıklarında verilen görevleri yapmakta isteksiz olmaları, ödev yapmamaları ve derse katılmama sorunlarıyla karşılaşıldığı sonucuna ulaşmışlardır.

Araştırmada, öğrencilerin okul olgunluklarının kurallara uyma bakımından okuma yazma sürecine etkisi ile ilgili olarak şu sonuca ulaşılmıştır. Okul olgunluğu kazanmış öğrencilerde kurallara uyma, derse hazırlıklı gelme, ödevleri zamanında yapma, düzenli tekrar yapma, sınıf içinde istenmedik davranış sergilememe, yönergeleri takip edebilme gibi becerilere sahip oldukları ve bu nedenle okuma yazma sürecinde daha başarılı oldukları sonucuna ulaşılmıştır. Okul olgunluğu kazanamamış öğrencilerin, kurallara uygun davranmakta zorlandığ sonrasında ödev, tekrar gibi sorumluklarını yerine getirmek istememe gibi davranışlarda bulunduklarına ve bu nedenlerle okuma yazma sürecinde geri kaldıklarına ve böylelikle, sürecin olumsuz etkilendiği sonucuna varılmıştır. Güzel ve Özyurt (2018) çalışmalarında, okul olgunluğu kazanmış öğrencilerin okul kurallarını anlayıp kurallara uyma ve bunları uygulayabilme özelliği gösterdiğini belirtmişlerdir. Gündüz ve Çalışkan (2013) ise, okul olgunluk düzeyi düşük olan öğrencilerin kurallara uymada bazı güçlükler yaşadıkları sonucuna varmışlardır.

Araştırmada elde edilen bir diğer sonuç ise; öz bakım becerileri bakımından okul olgunluğu kazanamayan öğrencilerin okuma yazma süreçlerinin olumsuz etkilendiğidir. Öz bakım becerisi kazanamamış öğrencilerin, beslenme yaparken çekindiği ve bunun sonucunda aç kalarak derse adapte olamamasının ve etkin katılım gösterememesinin, okuma yazma sürecini olumsuz etkilediği sonucuna ulaşılmıştır. Bunun yanı sıra tuvalet ihtiyacını teneffüslerde karşılamayı bilmeyen ya da kıyafetlerini düzenleyemediği için tuvalete gitmekten çekinen öğrencilerin, dersi takip etmekte zorlandığı, ders esnasında tuvalete gitmek durumunda kaldığından dersten çıkıp dersin 
bölünmesi nedeniyle süreci etkin takip edememesinin okuma yazma sürecini olumsuz etkilediği sonucuna varılmıştır. Ayrıca öz bakım yönünden yeterli olmayan öğrencilerin, yeterince temiz olamama durum ve düşüncesi öğrencinin, öğretmene yaklaşmaktan çekinmesine neden olduğuna ve bu durumun okuma yazma sürecini etkilediği sonucuna ulaşılmıştır. Başar (2013) çalışmasında ilkokula 60-66 ay aralığında başlayan öğrencilerin kişisel öz bakım ve ilk okuma yazma becerilerini değerlendirmiş ve çocukların öz bakım becerilerinin yeterince gelişmediğini, bu çocukların okula uyum problemi yaşadıklarını belirtmiştir. Erbasan ve Erbasan (2019), okul öncesi eğitim almayan öğrencilerin hazır bulunuşluklarının okuma yazma öğretimi için yeterli olmadığı sonucuna ulaşmıştır. Ayrıca bu öğrencilerin, öz bakım becerilerini tam olarak yerine getirememe ve derslerden çabuk sıkılma gibi çeşitli sorunlarla karşılaştı̆̆ı sonucuna varmıştır.

Sonuç olarak, bu araştırmada ilkokul 1.sınıf öğrencilerinin okul olgunluklarının okula uyum, sosyal beceriler, kurallara uyma ve öz bakım becerisi bakımından okuma yazma sürecini etkilediği sonucuna ulaşılmıştır. Arı ve Özcan (2014), birinci sınıf öğrencilerinin okul olgunluğu düzeylerinin, okuma yazmayı öğrenmelerine etkisi isimli çalışmalarında, okul olgunluğu ve okuma yazma becerisini karşılaştırmışlar, okul olgunluğu arttıkça öğrencilerin okuma yazma becerilerinin arttı̆̆ sonucuna ve okul olgunluğu zayıf olan öğrencilerin farkı kapatamadıkları ve bu durumun okuma yazma becerilerini etkilediği sonucuna ulaşmışlardır. Benzer bir çalışma olan Yangın (2009), çalışmasında ilkokul birinci sınıf öğrencilerinin hazır bulunuşlukları ile okuma yazma başarıları arasındaki ilişkiyi incelemiş ve hazır bulunuşluğun ve okul olgunluğunun okuma yazma başarılarında çok önemli bir değişken olduğu sonucuna ulaşmıştır.

Araştırmadan elde edilen sonuçlar göz önünde bulundurulduğunda şu öneriler getirilebilir:

- İlkokul 1.sınıfa başlayacak öğrencinin, takvim yaşına göre belirlenmesi yerine, her ilçede bulunan Rehberlik Araştırma Merkezleri tarafından okul olgunluk düzeylerini ölçen test sonuçlarına ve uzman raporuna göre öğrencinin okula başlatılmasına karar verilebilir.

- Okul olgunluğunu henüz yakalayamamış veya yeterli düzeye gelmeden okula başlatılmış olan öğrencilerin için rehber öğretmen, sınıf öğretmeni, okul idaresi ve veli iş birliği ile destekleyici programlar gerçekleştirilebilir. 
- $\quad$ Bu araştırma, araştırma sürecine veli görüşleri katılarak genişletilebilir.

- Araştırmacılar tarafından okul olgunluğunun farklı derslere etkisi incelenerek yeni araştırmalar yapılabilir. 


\title{
EXTENDED ABSTRACT
}

\section{The Effect of Student' School Maturity on the Literacy Process}

\author{
$*$ \\ Muhittin Sağırlı - Leyla Coşkun \\ İstanbul University - Cerrahpaşa - PhD Student at Marmara University Educational Sciences
}

The aim of this study is to examine teachers' opinions about the effect of school maturity of first grade students on the literacy process. In the study, teachers' views of the effect of students' school maturity on the literacy process in terms of school adjustment, motor skills, social skills, obedience to rules and self-care skills were examined. Accordingly, the following questions were sought:

1. What is the effect of students' school maturity on the literacy process in terms of adaptation to school?

2. What is the effect of students' school maturity on the literacy process in terms of motor development?

3. What is the effect of students' school maturity on the literacy process in terms of social skills?

4. What is the effect of students' school maturity on the literacy process in terms of their self-care skills?

5. What is the effect of students' school maturity on the literacy process in terms of obeying the rules?

In the study, teachers 'views on the effect of primary school first grade students' school maturity on the literacy process were examined. In this study, one of the qualitative research designs, case study was used. In case studies, an individual, an institution, a group, a setting can be examples of situations to be studied. The aim is to present the results for a particular situation. The most basic feature of the qualitative case study is the in-depth investigation of one or a few situations. In other words, the factors (environment, individuals, events, processes, etc.) related to a situation are investigated with a holistic approach and the focus is on how they affect the relevant situation and 
how they are affected by the relevant situation "(Y1ldırım and Şimşek, 2018, p.73).

The sample of the research consists of 15 easily accessible classroom teachers who work in different public schools in Istanbul during the 2020-2021 academic year and have taught first grades for at least two times. While determining the sample group,convenience sampling, which is one of the purposeful sampling methods, was used as a method.

In the study, a semi-structured interview form consisting of open-ended questions prepared by the researchers was used for the participants to collect data. Due to the Covid-19 epidemic, the interview forms were delivered to the participants as Google Form, and their answers were received and recorded on the Google Form.

In this study, content analysis, one of the qualitative data analysis methods, was performed in data analysis. In content analysis, similar data are collected, arranged and interpreted within the framework of certain concepts and themes. (Ylldırım and Şimşek, 2018). In this direction, the collected data were read one by one by coding as teacher 1 (T1), teacher 2 (T2), ... similar codes were created from the obtained data, and the generated codes were collected and analyzed under themes. The answers are digitized and the total numbers obtained are given in the tables.

In this study, the effect of school maturity of students who started the first grade on the literacy process was examined according to the teachers' opinions. In the light of the findings, the following conclusions have been reached:

According to the opinions of the classroom teachers, it was concluded that the school maturity of the students affected the literacy process in terms of adaptation to the school. From the opinions of the teachers, it was concluded that low school maturity negatively affected the student's literacy process, especially because of not wanting to leave the family, being afraid of school, family problems and being raised in overprotective families, which slowed down the adaptation process to school. In addition, it was concluded that students who have reached school maturity have a positive effect on the literacy process because they feel sympathy for the school, adapt easily to the school environment and have high motivation towards school.

One of the results obtained from the research findings is that students with high levels of school maturity in terms of motor development have more advanced skills such as holding the pencil correctly, following the lines, sitting 
in a row, and writing the direction of writing correctly, which has an effect on students' being more successful in the literacy process. In addition, it was concluded that students with high motor development benefit high self-confidence, and being acquainted with the book has a positive effect on eye coordination. In addition, according to the opinions of the teachers, it was concluded that whether the students have attended kindergarten and the month of the students' age affect the motor skill levels and, thus, the literacy process.

Another result of the study is that students who have gained school maturity in terms of social skills do not hesitate to express their difficulties during the lesson, as they do not have difficulty in expressing themselves, they can ask what they do not understand, and do not have difficulty in communicating with their friends and teachers. This situation positively affects the student's active participation in the literacy process as they can correct their mistakes during the process and thus be successful. Students who have not reached the level of school maturity in terms of social skills have self-esteem problems, hesitate to ask questions and feel that they are not included in the group as they feel behind and have difficulty in communicating with their friends. It was concluded that this situation caused students to be delayed in the literacy process.

According to the opinions of the teachers, the following conclusion was reached regarding the effect of students' school maturity on the literacy process in terms of obeying the rules. Students who have gained school maturity have skills such as obeying the rules, coming prepared for the lesson, doing homework on time, studying regularly, not exhibiting unwanted behaviors in the classroom, and being able to follow instructions and therefore they are more successful in the literacy process. On the other hand, the students who did not gain school maturity had difficulty in acting in accordance with the rules, such as not listening to the lesson during the lesson, not wanting to fulfill their responsibilities such as homework which delays their literacy process and therefore the process was negatively affected.

Another result obtained in the study is that the literacy processes of the students who have not gained school maturity in terms of self-care skills are negatively affected. Students who could not acquire self-care skills were embarrassed during lunch at school and as a result, their inability to adapt to the lesson due to being hungry negatively affected the literacy process. In addition, it was concluded that students who do not know how to meet their toilet 
needs during breaks, or who are embarrassed to go to the toilet because they cannot change their clothes, have difficulty following the lesson, and their inability to follow the process effectively due to the fact that they have to go to the toilet during the lesson negatively affects the literacy process. In addition, it was concluded that the insufficient cleanliness of the students who are not mature enough to meet their self-care causes the student to hesitate to approach the teacher and this situation affects the literacy process.

Considering the results obtained from the research, the following suggestions can be made:

- Instead of determining the students who will start primary school only by age, it would be healthier to make the decision in the light of scientific data by subjecting students to tests measuring their school maturity levels by the Guidance Research Centers in each district which reports to the Ministry of Education.

- Programs can be offered in cooperation with counselors, classroom teachers, school administration and parents in order to close the gap between students who have not reached school maturity or who have started school with poor school maturity and students who have reached school maturity.

- This research can be expanded by including parents' opinions in the research process.

- New research can be done by researchers by examining the effect of school maturity on different lessons.

\section{Kaynakça / References}

Arı, A. ve Özcan, E. (2014). Birinci sınıf öğrencilerinin okul olgunluğu düzeylerinin, okuma yazmayı öğrenmelerine etkisi. Dumlupınar Üniversitesi Sosyal Bilimler Dergisi, (47), 74-90.

Babayiğit, Ö. ve Erkuş, B. (2017). Illk okuma yazma öğretimi sürecinde sorunlar ve çözüm önerileri. Erzincan Üniversitesi Eğitim Fakültesi Dergisi, 19(2), 271-284.

Başar, M. ve Gürbüz, H. M. (2020). İlk okuma yazma öğretiminde karşllaşllan sorunlar ve çözüm önerileri .Okuma Yazma Eğitimi Araştırmaları, 8(1), 1-20.

Carlton, M. P. ve Winsler, A. (1999). School readiness: The need for a paradigm shift. School psychology review, 28(3), 338-352. 
Cinkılıç, H. (2009). Okul öncesi eğitimin ilköğretim 1.sinıföğrencilerinin okul olgunluğuna etkisinin incelenmesi. Yüksek lisans tezi, Selçuk Üniversitesi Sosyal Bilimler Enstitüsü, Konya.

Çelenk, S. (2008). İlköğretim okulları birinci sınıf öğrencilerinin ilkokuma ve yazma öğretimine hazırlık düzeyleri. Abant İzzet Baysal Üniversitesi Ĕ̆itim Fakültesi Dergisi. 8(1), 83-90.

Çökük, K. (2019). Farklı yaşlarda ilkokula başlayan öğrencilerin okula hazırbulunuşlukları ve uyum sorunları. Yüksek lisans tezi, Van Yüzüncü Yıl Üniversitesi, Van.

Ekinci, O. (2001). Okul öncesi eğitimin ilköğretim birinci sınff öğrencilerinin başarısına etkisi. Yayınlanmamış Yüksek Lisans Tezi, Gaziantep Üniversitesi Sosyal Bilimler Enstitüsü, Gaziantep.

Erkan, S. ve Kırca, A. (2010). Okul öncesi eğitimin ilköğretim birinci sınıf öğrencilerinin okula hazırbulunuşluklarına etkisinin incelenmesi. Hacettepe Üniversitesi Ĕ̈itim Fakültesi Dergisi, 38, 94-106.

Erkan, S. (2011). Farklı sosyoekonomik düzeydeki ilköğretim birinci sınıf öğrencilerinin okula hazırbulunuşluklarının incelenmesi. Hacettepe Üniversitesi Ĕ̆itim Fakültesi Dergisi, 40, 186-197.

Erbasan, Ö. ve Erbasan, Ü. (2020). Sınıf öğretmenlerinin ilk okuma yazma öğretimi sürecinde karşlaştı̆̆ı sorunlar. Ana Dili Eğitimi Dergisi, 8(1), 113-125.

Gündüz, F. ve Çalışkan, M. (2013). 60-66, 66-72, 72-84 aylık çocukların okul olgunluk ve okuma yazma becerilerini kazanma düzeylerinin incelenmesi. Turkish Studies, 8(8), 379-398.

Gündüz, H. B. ve Özarslan, N. (2017). Farklı yaş kategorilerinde ilkokula başlayan öğrencilerin okul olgunluğu ve öğretmen görüşlerine göre okula uyum problemleri. Abant İzet Baysal Üniversitesi Eğitim Fakültesi Dergisi, 17(1),212230.

Karakaş, B. (2015). Okul öncesi eğitim alan 60-72 aylık çocuklarda "okula hazırlık eğitimi "nin ilkokula hazırbulunuşluk düzeylerine etkisinin İncelenmesi. Yüksek lisans tezi, Ege Üniversitesi, İzmir.

Kaytaz, M. (2005). Türkiye'de okulöncesi eğitimin fayda-maliyet analizi. İstanbul: Anne Çocuk Eğitim Vakfi Yayınları.

Koçyiğit, S. (2009). İlköğretim birinci sınıf öğretmenlerinin ve ebeveynlerin görüşleri 1şığında okula hazırbulunuşluk olgusu ve okul öncesi eğitime ilişkin sonuçları. Yüksek lisans tezi, Selçuk Üniversitesi, Konya.

Oktay A. ve Unutkan Ö.P. (2005). İlköğretime hazır oluş ve okul öncesi eğitimle ilköğretimin karşılaştırılması. Erken çocuklukta gelişim ve eğitimde yeni yaklaşımlar içinde. İstanbul: Morpa Kültür Yayınları. 
Özcan, A. O. ve Özcan, A. F. (2014). Türk çocuklarının ses gelişim özellikleri ve ilk okuma yazma öğrenme. İstanbul Gelişim Üniversitesi Sosyal Bilimler Dergisi, 1 (2), 67-86.

Özbek, A. (2003). Okul öncesi eğitim kurumlarına devam eden ve etmeyen çocukların ilköğretim birinci sınıfta sosyal gelişim açısından öğretmen görüşüne dayalı incelenmesi. Yayınlanmamış Yüksek Lisans Tezi, Anadolu Üniversitesi Sosyal Bilimler Enstitüsü, Eskişehir.

Öztürk, E. ve Uysal, K. (2013). İlkokul 1.sınıf öğrencilerinin okuma-yazma süreçlerinin takvim yaşı yönünden. Electronic Turkish Studies, 8(8), 1041-1054.

Özyurt, M. ve Güzel, N. (2018). Okul öncesi eğitimi alan çocukların okul olgunluğu düzeylerinin ve okul olgunluğuna ilişkin öğretmen görüşlerinin incelenmesi. Mersin Üniversitesi Eğitim Fakültesi Dergisi, 14(3), 1250-1267.

Pehlivan, D. (2006). Okul öncesi eğitimi alan ve almayan öğrencilerin ilk okuma yazmaya geçiş sürecinin, öğretmen ve öğrenci görüşleri doğrultusunda değerlendirilmesi. Yüksek Lisans Tezi, Çukurova Üniversitesi Sosyal Bilimler Enstitüsü, Adana.

Sağ, R., Arslan, D., ve Karataş, Z. (2015). Comparing the written work of two age groups at the first grade. Procedia-Social and Behavioral Sciences, 191, 473-481.

Sağırl, M. (2019). İlkokuma yazma öğretiminin önemi, amacı ve birinci sını öğretmenliği. Ö. Yılar (Edt.), İkokuma ve yazma öğretimi (s. 1-30). Ankara: Pegem Akademi.

Tutal, Ö. ve Oral, B. (2015). İlk okuma- yazma öğrenmede okula başlama yaşının okuma-yazma başarısına etkisi. Dicle Üniversitesi Ziya Gökalp Eğitim Fakültesi Dergisi, (24), 96-121.

Vatansever-Bayraktar, H. ve Kendirci, M. (2018). Investigation of Primary School Students' School Readiness Levels. International Journal Of Eurasia Social Sciences, 9 (31), 808-853.

Yangın B. (2007). Okul öncesi eğitim kurumlarındaki altı yaş çocuklarının yazmayı öğrenmeye hazır bulunuşluk düzeyleri. Hacettepe Üniversitesi Eğitim Fakültesi Dergisi 32, 294-305.

Yavuzer, H. (2010). Çocuğun İlk 6 Yllı. İstanbul: Remzi Kitapevi.

Yıldırım, A. ve Şimşek, H. (2018). Sosyal bilimlerde nitel araştırma yöntemleri (11.Baskı). Ankara:Seçkin Yayıncılık.

Yoleri, S. ve Tanış ,H. M. (2014). İlkokul birinci sınıf öğrencilerinin okula uyum düzeylerini etkileyen değişkenlerin incelenmesi. Karabük Üniversitesi Sosyal Bilimler Enstitüsü Dergisi, 4 (2), 130-141. 
Yüce, S. ve Canbulat, A.N. (2017). Sınıf öğretmenlerinin ilkokuma yazma öğretiminde okul olgunluğu belirleme ve kullanma yeterliklerine ilişkin görüşleri. International Journal of Languages' Education and Teaching , 5(1), 101-123.

Kaynakça Bilgisi / Citation Information

Sağırlı, M. ve Coşkun, L. (2021). Öğrencilerin okul olgunluklarının okuma yazma sürecine etkisi. OPUS-Uluslararası Toplum Araştırmaları Dergisi, 17(37), 4072-4103. DOI: 10.26466/opus.913538 